\title{
Results of the Research on Prevention of Mobbing/Bullying as a Psycho-Social Stressor when Implementing Corporate Social Responsibility
}

\author{
Jolita Vveinhardt ${ }^{1}$ \& Regina Andriukaitiene ${ }^{1}$ \\ ${ }^{1}$ Lithuanian Sports University, Kaunas, Lithuania \\ Correspondence: Jolita Vveinhardt, Lithuanian Sports University, Sporto Str. 6, LT-44221 Kaunas, Lithuania. Tel: \\ 370-698-06668. E-mail: jolita.vveinhardt@gmail.com
}

This research was funded by a grant (No. The MIP-094/2014) from the Research Council of Lithuania.

Received: May 16, 2016

doi:10.5430/bmr.v5n2p42
Accepted: May 30, 2016

Online Published: June 12, 2016

URL: http://dx.doi.org/10.5430/bmr.v5n2p42

\begin{abstract}
This paper examines the results of the empirical research aimed to identify the prevalence of mobbing/bullying as a psycho-social stressor in socially responsible organizations as well as in the ones that do not adhere to a sense of corporate social responsibility. The aim of the research: to identify the prevalence of MBPS in organizations carrying corporate social responsibility and in organizations not practicing corporate social responsibility. The objectives of the research: (1) to validate the methodology of the research specifying the structure of the instrument; (2) to present the psychosomatic characteristics of the instrument; (3) to assess the prevalence of MBPS in regard to socio-demographic criteria. The methods of the research: analysis and synthesis of scientific literature, questionnaire survey based on validated questionnaire, statistical analysis and comparison. The paper presents the introduction, the methodology of the research, the psycho-metric characteristics of the questionnaire and the socio-demographic data from the respondents as well other aspects in regard to the data.
\end{abstract}

Keywords: Mobbing, Bullying, Corporate social responsibility, Psychosocial stressor, Prevention

\section{Introduction}

\subsection{Research Relevance}

Highly positive attitudes about corporate social responsibility that organizations integrate into their operations frequently prevail in society. It is considered such organizations should set a pattern for all others in regard to corporate social responsibility they have made it to be their primary focuses. However, as is it appears, even these organizations cannot avoid the problem of mobbing/bullying. Nonetheless, research on this issue to be analyzed in the context of corporate social responsibility is not abundant. It is of relevance to analyze the extent to which this phenomenon is prevalent in organizations carrying social responsibility as well as in those that have not declared corporate social responsibility. No less significant is the analysis of employee's socio-demographic characteristics, i.e., how the problem of mobbing/bullying reveals itself in a socio-demographic aspect when implementing corporate social responsibility. This is of significance if compared with the results of other surveys and when preparing recommendations for change.

\subsection{Research Problem}

The extent of mobbing/bullying as a psycho-social stressor (hereafter MBPS) prevalence in organizations having the status of corporate social responsibility (hereafter CSR) and in organizations not having the status of corporate social responsibility as well as the dissemination of the percentage of employees' acceptance in regard to the socio-demographic characteristics and their components.

\subsection{Problem Research Level}

The research on diagnosing mobbing in relationships between employees is extremely abundant when analyzing this issue in the work of nurses (Yildirim, A., Yildirim, D., 2007; Efe, Ayaz, 2010; Motlova, Lemrova, 2013; Baran Aksakal et al., 2015; etc.), as well as in the field of professional activity of education, in academic community (Faria 
et al., 2012; Sotomayor, Pando, 2014; etc.). A number of studies, which do not distinguish areas of professional activity when analyzing the phenomenon of mobbing, were carried out (Cramaruc, 2011; Žukauskas et al., 2015). Some of the workplace mobbing studies highlights the gender aspect (Escartin et al., 2013; Mulder et al., 2014; etc.). They also deal with the cases of employees' health (de Pedro et al. 2008), diseases caused by mobbing, and suicide cases (Hugh, 2011).

\section{Research Methodology}

The questionnaire made up by the authors of this paper was checked up carrying the pilot research $(\mathrm{N}=301)$ (Vveinhardt, Andriukaitienè, 2015). Although the psychosometric characteristics of the questionnaire have been set quite high, it was the authors' decision to apply a few slight corrections. Thus, it was reasonable to appropriately test it in the case of a larger sample $(\mathrm{N}=1512)$. Table 1 provides a detailed structure of the instrument used in this research.

Table 1. The Instrument Structure

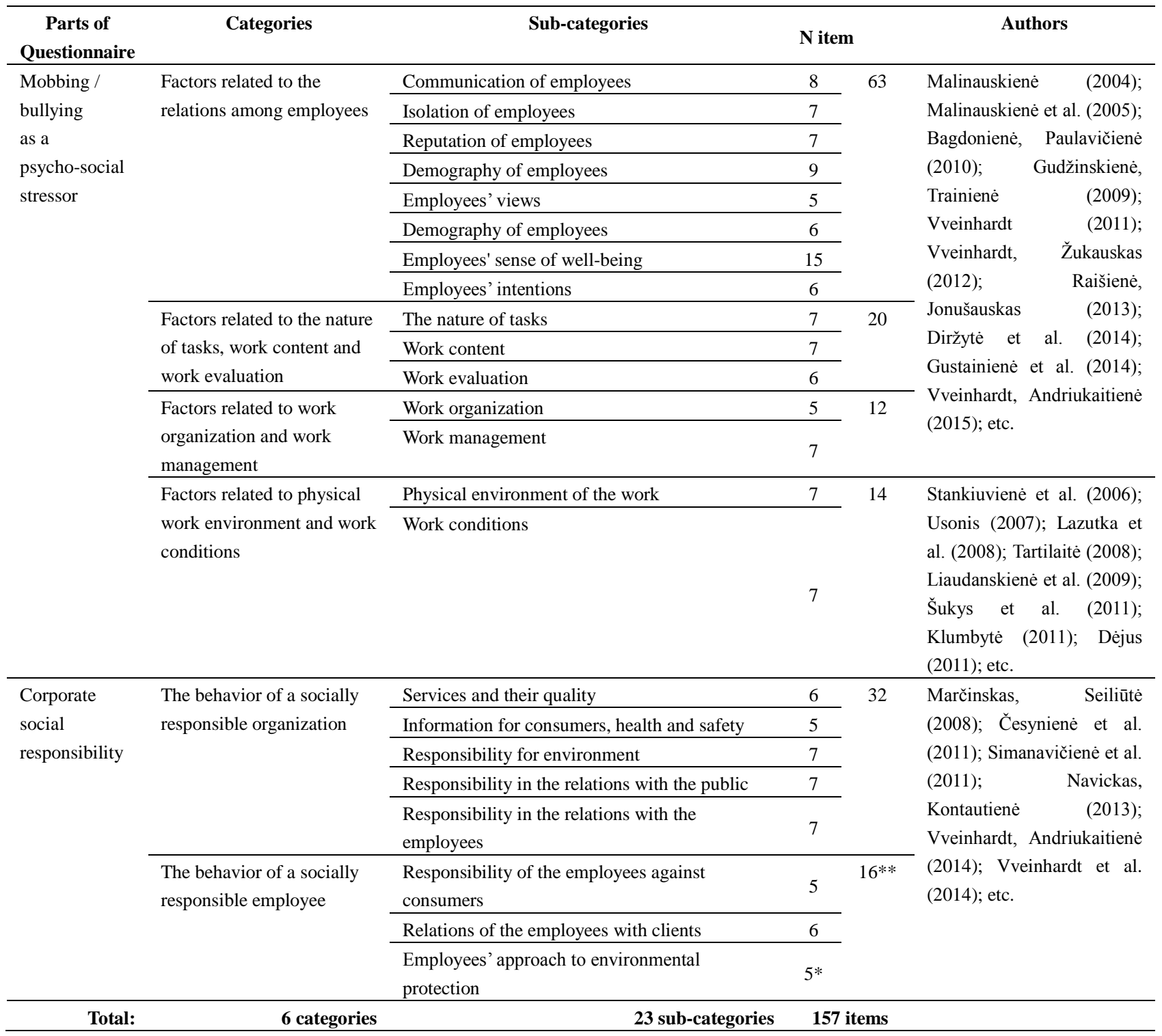

Notes:

*The pilot research included 4 items; "Motivating employees financially would encourage ideas and initiatives for environment protection "is a new integrated item;

** The pilot research included 15 items. 
The information that was retrieved from the questionnaire sub-categories presented in detail gives an overall picture of what it might be possible to focus on with the help of this instrument. The items of the sub-categories alongside the research results will be presented in the next section of this paper. Some questionnaire items were formulated with reference to the publications by the authors whose names can be seen in Table 1 .

\subsection{Questionnaire Psychometric Characteristics}

The psychometric characteristics of the questionnaire were checked by calculating the percentage of the explained dissemination, Cronbach alpha and Spearman Brown coefficients as well as by measuring factorial weight and the percentage of the explained dissemination at three levels (minimum, maximum and medium).

Table 2. Sub-category Methodological Quality Characteristics of Factors Related to the Relations among Employees $(\mathrm{N} \min =1512 ; \mathrm{N} \max =1512$ of 1512$)$

\begin{tabular}{|c|c|c|c|c|c|c|c|c|c|c|}
\hline \multirow[t]{2}{*}{ Sub-categories } & \multirow[t]{2}{*}{$\begin{array}{c}\mathbf{N} \\
\text { items }\end{array}$} & \multirow{2}{*}{$\begin{array}{c}\text { Explained } \\
\text { dissemination } \\
\%\end{array}$} & \multirow[t]{2}{*}{$\begin{array}{c}\text { Cronbach } \\
\text { alpha }\end{array}$} & \multirow[t]{2}{*}{$\begin{array}{l}\text { Spearman- } \\
\text { Brown }\end{array}$} & \multicolumn{3}{|c|}{$\begin{array}{l}\text { Factorial weight } \\
\text { (L) }\end{array}$} & \multicolumn{3}{|c|}{$\begin{array}{c}\text { Whole unit correlation } \\
\text { (r/itt) }\end{array}$} \\
\hline & & & & & mean & $\min$ & $\max$ & mean & $\min$ & $\max$ \\
\hline Communication of employees & 8 & 58.80 & 0.89 & 0.79 & 0.76 & 0.66 & 0.84 & 0.58 & 0.36 & 0.92 \\
\hline Isolation of employees & 7 & 71.24 & 0.93 & 0.90 & 0.84 & 0.82 & 0.88 & 0.71 & 0.60 & 0.88 \\
\hline Reputation of employees & 7 & 68.46 & 0.92 & 0.90 & 0.83 & 0.74 & 0.86 & 0.68 & 0.52 & 0.87 \\
\hline Demography of employees & 9 & 70.97 & 0.95 & 0.92 & 0.84 & 0.72 & 0.90 & 0.71 & 0.48 & 0.88 \\
\hline Employees'views & 5 & 71.15 & 0.90 & 0.84 & 0.84 & 0.77 & 0.89 & 0.71 & 0.46 & 0.90 \\
\hline Damage suffered by employees & 6 & 76.23 & 0.94 & 0.89 & 0.87 & 0.81 & 0.92 & 0.76 & 0.60 & 0.91 \\
\hline Employees' sense of well-being & 15 & 59.26 & 0.95 & 0.92 & 0.77 & 0.67 & 0.84 & 0.59 & 0.30 & 0.83 \\
\hline Employees' intentions & 6 & 69.33 & 0.91 & 0.89 & 0.83 & 0.69 & 0.90 & 0.69 & 0.48 & 0.89 \\
\hline
\end{tabular}

As it can be seen from the research results presented in Table 2, Cronbach alpha coefficient values in these sub-categories are rather high, i.e., range from 0.89 (minimum value in the category) to 0.95 (the maximum value in the category). Cronbach alpha coefficient value should not be lower than 0.7. The explained factor dispersion in the sub-categories presented in the Table takes the interval: 58.80 - 76.2 per cent, which shows a rather high level of the respondents' acceptance as the explained factor dispersion must be greater than the allowable lowest 10 per cent limit. Here the minimum factor weight ranges from 0.66 to 0.82 . It should be noted that even the lowest factorial weight exceeds the minimum limit of 0.3 . The whole unit correlation just confirms that there is a consistent correlation between the questionnaire items and the named sub-category as r/itt average ranges from 0.58 to 0.76 ; as it is known, the whole unit correlation should not be less than 0.2.

Table 3. Sub-category Methodological Quality Characteristics of Factors Related to the Nature of Tasks, Work Content and Work Evaluation $(\mathrm{N} \min =1512 ; \mathrm{N} \max =1512$ of 1512)

\begin{tabular}{|c|c|c|c|c|c|c|c|c|c|c|c|}
\hline \multirow[t]{2}{*}{ Sub-categories } & \multirow[b]{2}{*}{ Items } & \multirow[t]{2}{*}{$\begin{array}{c}\mathbf{N} \\
\text { items }\end{array}$} & \multirow{2}{*}{$\begin{array}{c}\text { Explained } \\
\text { dissemination } \\
\%\end{array}$} & \multirow[t]{2}{*}{$\begin{array}{l}\text { Cronbach } \\
\text { alpha }\end{array}$} & \multirow[t]{2}{*}{$\begin{array}{l}\text { Spearman- } \\
\text { Brown }\end{array}$} & \multicolumn{3}{|c|}{$\begin{array}{c}\text { Factorial weight } \\
\text { (L) } \\
\end{array}$} & \multicolumn{3}{|c|}{$\begin{array}{c}\text { Whole unit correlation } \\
(\mathrm{r} / \mathrm{itt})\end{array}$} \\
\hline & & & & & & mean & $\min$ & $\max$ & mean & $\min$ & $\max$ \\
\hline The nature of tasks & & 7 & 61.61 & & 0.84 & 0.78 & 0.61 & 0.86 & 0.61 & 0.26 & 0.85 \\
\hline Work content & & 7 & 50.82 & 0.84 & 0.71 & 0.71 & 0.62 & 0.84 & 0.49 & 0.19 & 0.82 \\
\hline Work evaluation & & 6 & 69.81 & 0.91 & 0.88 & 0.83 & 0.78 & 0.86 & 0.69 & 0.52 & 0.87 \\
\hline
\end{tabular}

The research results in Table 3 show that the Cronbach alpha coefficient values in the named subcategories are high (from 0.84 to 0.91 ). The explained factor dispersion ranges from 50.82 to 69.81 . Minimum factorial weight is $0.61-$ 0.78 , the correlation average of the whole unit is from 0.49 to 0.69 , which makes it possible to diagnose that the items of sub-categories are closely interrelated.

Table 4. Sub-category Methodological Quality Characteristics of Factors Related to Work Organization and Work Management $(\mathrm{N} \min =1512 ; \mathrm{N} \max =1512$ of 1512)

\begin{tabular}{|c|c|c|c|c|c|c|c|c|c|c|c|}
\hline \multirow[t]{2}{*}{ Sub-categories } & \multirow[b]{2}{*}{ Items } & \multirow[t]{2}{*}{$\begin{array}{c}\mathbf{N} \\
\text { items }\end{array}$} & \multirow{2}{*}{$\begin{array}{c}\text { Explained } \\
\text { dissemination } \\
\% \\
\end{array}$} & \multirow[t]{2}{*}{$\begin{array}{c}\text { Cronbach } \\
\text { alpha }\end{array}$} & \multirow[t]{2}{*}{$\begin{array}{l}\text { Spearman- } \\
\text { Brown }\end{array}$} & \multicolumn{3}{|c|}{$\begin{array}{c}\text { Factorial weight } \\
\text { (L) } \\
\end{array}$} & \multicolumn{3}{|c|}{$\begin{array}{c}\text { Whole unit correlation } \\
\text { (r/itt) }\end{array}$} \\
\hline & & & & & & mean & $\min$ & $\max$ & mean & $\min$ & $\max$ \\
\hline Work organization & & 5 & 72.54 & 0.91 & 0.86 & 0.85 & 0.81 & 0.89 & 0.72 & 0.59 & 0.89 \\
\hline Work management & & 7 & 74.08 & 0.94 & 0.92 & 0.86 & 0.83 & 0.88 & 0.74 & 0.63 & 0.88 \\
\hline
\end{tabular}

Notes:

All the items were recoded 
Table 5. Sub-category Methodological Quality Characteristics of Factors Related to Physical Environment of the Work and Work Conditions $(\mathrm{N} \min =1512 ; \mathrm{N} \max =1512$ of 1512$)$

\begin{tabular}{|c|c|c|c|c|c|c|c|c|c|c|}
\hline \multirow[t]{2}{*}{ Sub-categories } & \multirow[t]{2}{*}{$\begin{array}{c}\mathbf{N} \\
\text { items }\end{array}$} & \multirow{2}{*}{$\begin{array}{c}\text { Explained } \\
\text { dissemination } \\
\%\end{array}$} & \multirow[t]{2}{*}{$\begin{array}{c}\text { Cronbach } \\
\text { alpha }\end{array}$} & \multirow[t]{2}{*}{$\begin{array}{l}\text { Spearman- } \\
\text { Brown }\end{array}$} & \multicolumn{3}{|c|}{$\begin{array}{c}\text { Factorial weight } \\
\text { (L) }\end{array}$} & \multicolumn{3}{|c|}{$\begin{array}{c}\text { Whole unit correlation } \\
(\mathrm{r} / \mathrm{itt})\end{array}$} \\
\hline & & & & & mean & $\min$ & $\max$ & mean & $\min$ & $\max$ \\
\hline $\begin{array}{l}\text { Physical environment of the } \\
\text { work }\end{array}$ & 7 & 62.46 & 0.90 & 0.85 & 0.79 & 0.73 & 0.85 & 0.62 & 0.40 & 0.84 \\
\hline Work conditions & 7 & 60.00 & 0.89 & 0.86 & 0.77 & 0.62 & 0.86 & 0.59 & 0.34 & 0.84 \\
\hline
\end{tabular}

Notes:

All the items were recoded

The analysis of the research results presented in Table 4 and Table 5 show that the stronger acceptance by the respondents is seen with regard to work management, i.e., both the explained factor dispersion (74.08) and Cronbach alpha (0.92) coefficient values are rather high (in the sub-categories of the category named "Factors related to work organization and work management" (Table 4). Even though the indicators of the "work organization' sub-category are slightly lower, however, the value of Cronbach alpha coefficient is also rather high 0.86 , but in this case the explained factor dispersion is slightly lower (72.5), if to compare the two latter subcategories. The minimum factorial weight in the sub-categories of this category is in accordance with the requirements of questionnaires as its values range from 0.81 to 0.83 , while the correlation average of the whole unit ranges from 0.72 to 0.74 . As far as it can be seen from the analysis of the sub-category psychometric characteristics in the category named "Factors related to the physical work environment and work conditions" (Table 5), physical environment of the work has been valued 62.4 per cent (the explained dissemination per cent), while Cronbach alpha coefficient value is 0.90 . The indicators of the work conditions sub-category are slightly lower; however, the value of Cronbach alpha coefficient is also rather high 0.89 while the explained dissemination is 60 per- cent. The value of minimum factorial weight ranges from 0.62 to 0.73 and the correlation average of the whole unit ranges from 0.59 to 0.62 . Thus, it can be stated that the indicators of the analyzed categories comply with the essential requirements of questionnaire reliability.

Table 6. Sub-category Methodological Quality Characteristics of Factors Related to the Behavior of a Socially Responsible Organization $(\mathrm{N} \min =1512 ; \mathrm{N} \max =1512$ of 1512 )

\begin{tabular}{|c|c|c|c|c|c|c|c|c|c|c|}
\hline \multirow[t]{2}{*}{ Sub-categories } & \multirow[t]{2}{*}{$\begin{array}{c}\mathbf{N} \\
\text { items }\end{array}$} & \multirow{2}{*}{$\begin{array}{c}\text { Explained } \\
\text { dissemination } \\
\% \\
\end{array}$} & \multirow[t]{2}{*}{$\begin{array}{l}\text { Cronbach } \\
\text { alpha }\end{array}$} & \multirow[t]{2}{*}{$\begin{array}{l}\text { Spearman- } \\
\text { Brown }\end{array}$} & \multicolumn{3}{|c|}{$\begin{array}{l}\text { Factorial weight } \\
\text { (L) }\end{array}$} & \multicolumn{3}{|c|}{$\begin{array}{l}\text { Whole unit correlation } \\
\text { (r/itt) }\end{array}$} \\
\hline & & & & & mean & $\min$ & $\max$ & mean & $\min$ & $\max$ \\
\hline Services and their quality & 6 & 68.83 & 0.91 & 0.85 & 0.83 & 0.79 & 0.87 & 0.68 & 0.51 & 0.86 \\
\hline $\begin{array}{l}\text { Information for consumers, health } \\
\text { and safety }\end{array}$ & 5 & 72.78 & 0.91 & 0.87 & 0.85 & 0.82 & 0.89 & 0.72 & 0.58 & 0.88 \\
\hline Responsibility for environment & 7 & 69.60 & 0.93 & 0.88 & 0.83 & 0.74 & 0.89 & 0.69 & 0.50 & 0.88 \\
\hline $\begin{array}{l}\text { Responsibility in the relations } \\
\text { with the public }\end{array}$ & 7 & 65.03 & 0.92 & 0.91 & 0.81 & 0.74 & 0.87 & 0.64 & 0.41 & 0.85 \\
\hline $\begin{array}{l}\text { Responsibility in the relations } \\
\text { with the employees }\end{array}$ & 7 & 63.14 & 0.90 & 0.86 & 0.79 & 0.67 & 0.84 & 0.62 & 0.41 & 0.83 \\
\hline
\end{tabular}

The results in Table 6 show that the value of Cronbach alpha coefficient in the analyzed sub-categories varies from 0.90 to 0.93 . The explained factor dispersion is also very high, i.e., the lowest per cent is 63.14 and the highest per cent is 72.78 . The minimum factorial weight of the sub-categories within the category is 0.67 (minimum value) 0.82 (maximum value). The whole unit correlation shows that the lowest average is 0.62 and the highest average is 0.72 , thus, confirming the fact that the questionnaire statements are in correlation with the named sub-categories and that the statements of the sub-categories are in close interrelation. 
Table 7. Sub-category Methodological Quality Characteristics of Factors Related to the Behavior of a Socially Responsible Employee $(\mathrm{N} \min =1214 ; \mathrm{N} \max =1512$ of 1512)

\begin{tabular}{|c|c|c|c|c|c|c|c|c|c|c|}
\hline \multirow[t]{2}{*}{ Sub-categories } & \multirow[t]{2}{*}{$\begin{array}{c}\mathbf{N} \\
\text { items }\end{array}$} & \multirow{2}{*}{$\begin{array}{c}\text { Explained } \\
\text { dissemination } \\
\%\end{array}$} & \multirow[t]{2}{*}{$\begin{array}{l}\text { Cronbach } \\
\text { alpha }\end{array}$} & \multirow[t]{2}{*}{$\begin{array}{l}\text { Spearman- } \\
\text { Brown }\end{array}$} & \multicolumn{3}{|c|}{$\begin{array}{c}\text { Factorial weight } \\
\text { (L) }\end{array}$} & \multicolumn{3}{|c|}{$\begin{array}{c}\text { Whole unit correlation } \\
(\mathrm{r} / \mathrm{itt})\end{array}$} \\
\hline & & & & & mean & $\min$ & $\max$ & mean & $\min$ & $\max$ \\
\hline $\begin{array}{l}\text { Responsibility of the employees } \\
\text { against consumers }\end{array}$ & 5 & 76.14 & 0.92 & 0.88 & 0.87 & 0.83 & 0.92 & 0.76 & 0.62 & 0.91 \\
\hline $\begin{array}{l}\text { Responsibility of the employees } \\
\text { against customers }\end{array}$ & 6 & 78.61 & 0.95 & 0.89 & 0.89 & 0.80 & 0.92 & 0.78 & 0.60 & 0.92 \\
\hline $\begin{array}{l}\text { Employees approach to } \\
\text { environmental protection }\end{array}$ & 5 & 59.10 & 0.81 & 0.76 & 0.75 & 0.43 & 0.86 & 0.56 & 0.20 & 0.83 \\
\hline
\end{tabular}

Notes:

All the items of Scale 1 and Scale 3 were recoded

As it can be seen from the sub-category methodological quality characteristics of the factors related to the behavior of a socially responsible employee presented in Table 7 that Cronbach alpha coefficient value is from 0.81 to 0.95 . It proves notable internal consistency of the questionnaire sub-categories. The explained factor dispersion ranges from 59.10 per cent to 76.1 per cent. The minimum factorial weight in these subcategories varies from 0.43 to 0.83 . The correlation average of the whole unit within the sub-categories is $0.56-0.76$.

Table 8. The Instrument Sub-category Methodological Quality Characteristics in Regard to Explained Dissemination Percentage and Cronbach Alpha Coefficient

\begin{tabular}{|c|c|c|c|}
\hline Sub-categories & $\begin{array}{c}\begin{array}{c}\text { Explained } \\
\text { dissemination } \\
\%\end{array} \\
\text { Over } 70 \%\end{array}$ & Sub-categories & Cronbach alpha \\
\hline Relations of employees with the clients & 78.61 & $\begin{array}{l}\text { Relations of the employees } \\
\text { with clients }\end{array}$ & 0.95 \\
\hline Damage suffered by employees & 76.23 & $\begin{array}{lll}\begin{array}{l}\text { Employees' } \\
\text { well-being }\end{array} & \text { sense } & \text { of } \\
\end{array}$ & 0,95 \\
\hline $\begin{array}{l}\begin{array}{l}\text { Responsibility of the employees } \\
\text { consumers }\end{array} \\
\end{array}$ & 76.14 & Demography of employees & 0.95 \\
\hline Work management & 74.08 & $\begin{array}{lll}\begin{array}{l}\text { Damage } \\
\text { employees }\end{array} & \text { suffered } & \text { by }\end{array}$ & 0.94 \\
\hline Information for consumers, health and safety & 72.78 & Work management & 0.94 \\
\hline Work organization & 72.54 & Isolation of employees & 0.93 \\
\hline Isolation of employees & 71.24 & $\begin{array}{ll}\text { Responsibility } & \text { for } \\
\text { environment } & \end{array}$ & 0.93 \\
\hline Employees' views & 71.15 & $\begin{array}{l}\text { Employees’ responsibility } \\
\text { against consumers }\end{array}$ & 0.92 \\
\hline Demography of employees & 70.97 & Reputation of employees & 0.92 \\
\hline Sub-categories & From 60 to $70 \%$ & $\begin{array}{l}\text { Responsibility in the } \\
\text { relations with the public }\end{array}$ & 0.92 \\
\hline Work evaluation & 69.81 & $\begin{array}{l}\text { Information for consumers, } \\
\text { health and safety }\end{array}$ & 0.91 \\
\hline Responsibility for environment & 69.60 & Work organization & 0.91 \\
\hline Employees' intentions & 69.33 & Work evaluation & 0.91 \\
\hline Services and their quality & 68.83 & Employees' intentions & 0.91 \\
\hline Reputation of employees & 68.46 & Services and their quality & 0.91 \\
\hline Responsibility in the relations with the public & 65.03 & Employees' views & 0.90 \\
\hline $\begin{array}{l}\begin{array}{l}\text { Responsibility in the relations with the } \\
\text { employees }\end{array} \\
\end{array}$ & 63.14 & $\begin{array}{l}\text { Responsibility in the } \\
\text { relations with the employees }\end{array}$ & 0.90 \\
\hline Physical environment of the work & 62.46 & $\begin{array}{l}\text { Physical environment of the } \\
\text { work }\end{array}$ & 0.90 \\
\hline The nature of tasks & 61.61 & - & - \\
\hline Work conditions & 60.00 & - & - \\
\hline $\begin{array}{l}\text { Sub-categories } \\
\end{array}$ & From 50 to $60 \%$ & Sub-categories & Over $\mathbf{0 , 8 0}$ \\
\hline Employees' sense of well-being & 59.26 & The nature of tasks & 0.89 \\
\hline $\begin{array}{l}\text { Employees' approach to environmental } \\
\text { protection }\end{array}$ & 59.10 & Work conditions & 0.89 \\
\hline Communication of employees & 58.80 & $\begin{array}{l}\text { Communication of } \\
\text { employees }\end{array}$ & 0.89 \\
\hline Work content & 50.82 & Work content & 0.84 \\
\hline - & - & $\begin{array}{l}\text { Employees' approach to } \\
\text { environmental protection }\end{array}$ & 0.81 \\
\hline
\end{tabular}

Looking at the overall picture of the instrument in regard to the psychometric characteristics, certain qualitative points can be highlighted. In order to summarize the results retrieved from the psychometric characteristics, the comparison of the instrument sub-categories was made (Table 8). The highest per cent of the explained dispersion was recorded in nine subcategories (over 70 per cent), namely, employees' relations with customers, damage suffered by employees, responsibility of employees against consumers, work management, information for consumers, health 
and safety, work organization, isolation of employees, employees' views and demography of employees. A high per cent (over 60 per cent) was recorded in ten subcategories: work evaluation, responsibility for environment, employees' intentions, services and their quality, reputation of employees, responsibility in the relations with the public, responsibility in the relations with the employees, physical environment of the work, the nature of tasks and work conditions. In four sub-categories the explained factor dispersion is over 50 per cent which shows notably strong respondents' acceptance: employees' sense of well-being, employees' approach to environmental protection, communication of employees and work content. The highest indicators of Cronbach alpha coefficient were recorded in eighteen sub-categories (9.00 and over), while the coefficient in the rest five sub-categories is also notably high, i.e., over 8.00 .

Table 9. The Instrument Sub-category Methodological Quality Characteristics in Regard to Minimal Factorial Weight and Explained Dissemination Per cent

\begin{tabular}{|c|c|c|c|}
\hline \multirow[t]{2}{*}{ Sub-categories } & $\begin{array}{l}\text { Minimal factorial } \\
\text { weight }(\mathrm{L})\end{array}$ & \multirow[t]{2}{*}{ Sub-categories } & \multirow{2}{*}{$\begin{array}{c}\begin{array}{c}\text { Correlation of the whole } \\
\text { unit } \\
\text { (r/itt) }\end{array} \\
\text { Over } 0.70 \\
\end{array}$} \\
\hline & Over 0.80 & & \\
\hline Work management & 0.83 & Employees' relations with customers & 0.78 \\
\hline $\begin{array}{l}\text { Responsibility of the employees } \\
\text { against consumers }\end{array}$ & 0.83 & $\begin{array}{l}\text { Responsibility of the employees against } \\
\text { consumers }\end{array}$ & 0.76 \\
\hline Isolation of employees & 0.82 & Damage suffered by employees & 0.76 \\
\hline $\begin{array}{l}\text { Information for consumers, health and } \\
\text { safety }\end{array}$ & 0.82 & Work management & 0.74 \\
\hline Damage suffered by employees & 0.81 & Work organization & 0.72 \\
\hline Work organization & 0.81 & $\begin{array}{l}\text { Information for consumers, health and } \\
\text { safety }\end{array}$ & 0.72 \\
\hline Employees' relations with clients & 0.80 & Isolation of employees & 0.71 \\
\hline - & - & Employees' views & 0.71 \\
\hline - & - & Demography of employees & 0.71 \\
\hline Sub-categories & Over 0.70 & Sub-categories & Over 0.60 \\
\hline Services and their quality & 0.79 & Employees' intentions & 0.69 \\
\hline Work evaluation & 0.78 & Work evaluation & 0.69 \\
\hline Employees' views & 0.77 & Responsibility for environment & 0.69 \\
\hline Reputation of employees & 0.74 & Reputation of employees & 0.68 \\
\hline Responsibility for environment & 0.74 & Services and their quality & 0.68 \\
\hline $\begin{array}{l}\text { Responsibility in the relations with the } \\
\text { public }\end{array}$ & 0.74 & $\begin{array}{l}\text { Responsibility in the relations with the } \\
\text { public }\end{array}$ & 0.64 \\
\hline Physical environment of the work & 0.73 & Physical environment of the work & 0.62 \\
\hline Demography of employees & 0.72 & $\begin{array}{l}\text { Responsibility in the relations with the } \\
\text { employees }\end{array}$ & 0.62 \\
\hline- & - & The nature of tasks & 0.61 \\
\hline Sub-categories & Over 0.60 & Sub-categories & Over 0.50 \\
\hline Employees' intentions & 0.69 & Employees' sense of well-being & 0.59 \\
\hline Employees' sense of well-being & 0.67 & Work conditions & 0.59 \\
\hline $\begin{array}{l}\text { Responsibility in the relations with the } \\
\text { employees }\end{array}$ & 0.67 & Communication of employees & 0.58 \\
\hline Communication of employees & 0.66 & Relations of the employees with clients & 0.56 \\
\hline Work content & 0.62 & - & - \\
\hline Work conditions & 0.62 & - & - \\
\hline The nature of tasks & 0.61 & - & - \\
\hline Sub-categories & Over 0.40 & Sub-categories & Over 0.40 \\
\hline $\begin{array}{l}\text { Employees' approach to environmental } \\
\text { protection }\end{array}$ & 0.43 & Work content & 0.49 \\
\hline
\end{tabular}

In the overall context of the instrument the minimum factorial weight varies from 0.43 to 0.83 . The factorial weight is 0.43 in just one sub-category, i.e., the employees' approach to environmental protection. The correlation average of the whole unit, in regard to the subcategories, is rather high, too, i.e., from 0.49 to 0.78 . The minimum average was 
recorded in just one sub-category, i.e., the content of work (Table 9).

Table 10. The Correlation Indicators between MBPS and CSR $(\mathrm{Nmin}=1244 ; \mathrm{Nmax}=1512)$

\begin{tabular}{|c|c|c|c|c|c|c|c|c|c|}
\hline Parts of Questionnaire & \multicolumn{9}{|l|}{ CSR } \\
\hline \multirow{31}{*}{ MBPS } & Sub-categories & 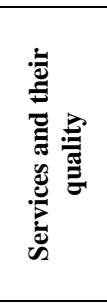 & 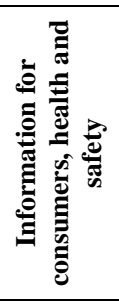 & 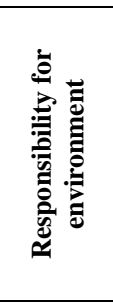 & 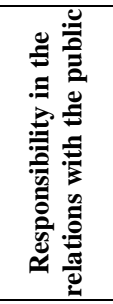 & 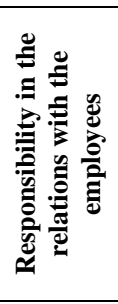 & 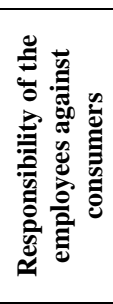 & 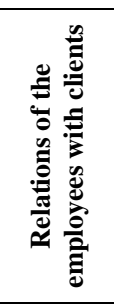 & 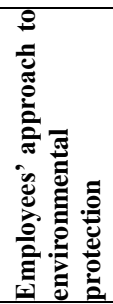 \\
\hline & \multirow{2}{*}{$\begin{array}{l}\text { Communication } \\
\text { of employees }\end{array}$} & $-.146^{* *}$ & $-.123 * *$ & $-.084 * *$ & $-.153 * *$ & $-.169 * *$ & $-.228 * *$ & $-.084 * *$ & $-.185^{* * *}$ \\
\hline & & 0.000 & 0.000 & 0.001 & 0.000 & 0.000 & 0.000 & 0.003 & 0.000 \\
\hline & \multirow{2}{*}{$\begin{array}{l}\text { Isolation } \\
\text { employees }\end{array}$} & $-.241 * *$ & $-.234 * *$ & $-.147 * *$ & $-.197 * *$ & $-.248 * *$ & $-.229 * *$ & $-.125 * *$ & $-.179 * *$ \\
\hline & & 0.000 & 0.000 & 0.000 & 0.000 & 0.000 & 0.000 & 0.000 & 0.000 \\
\hline & \multirow{2}{*}{$\begin{array}{l}\text { Reputation of } \\
\text { employees }\end{array}$} & $-.210^{* *}$ & $-.207 * *$ & $-.123 * *$ & $-.180^{* *}$ & $-.266^{* *}$ & $-.285^{* *}$ & $-.132 * *$ & $-.203 * *$ \\
\hline & & 0.000 & 0.000 & 0.000 & 0.000 & 0.000 & 0.000 & 0.000 & 0.000 \\
\hline & \multirow{2}{*}{$\begin{array}{l}\text { Demography of } \\
\text { employees }\end{array}$} & $-.216^{* *}$ & $-.198 * *$ & $-.107 * *$ & $-.148 * *$ & $-.126^{* * *}$ & $-.317 * *$ & $-.187 * *$ & $-.158 * *$ \\
\hline & & 0.000 & 0.000 & 0.000 & 0.000 & 0.000 & 0.000 & 0.000 & 0.000 \\
\hline & \multirow{2}{*}{$\begin{array}{l}\text { Employees' } \\
\text { views }\end{array}$} & $-.223 * *$ & $-.241^{* *}$ & $-.130 * *$ & $-.189 * *$ & $-.203^{* *}$ & $-.282 * *$ & $-.152^{* * *}$ & $-.164 * *$ \\
\hline & & 0.000 & 0.000 & 0.000 & 0.000 & 0.000 & 0.000 & 0.000 & 0.000 \\
\hline & \multirow{2}{*}{$\begin{array}{l}\text { Damage } \\
\text { suffered by } \\
\text { employees }\end{array}$} & $-.343 * *$ & $-.305 * *$ & $-.167 * *$ & $-.231 * *$ & $-.219 * *$ & $-.376 * *$ & $-.180 * *$ & $-.228 * *$ \\
\hline & & 0.000 & 0.000 & 0.000 & 0.000 & 0.000 & 0.000 & 0.000 & 0.000 \\
\hline & \multirow{2}{*}{$\begin{array}{l}\text { Employees' } \\
\text { sense of } \\
\text { well-being }\end{array}$} & $-.314 * *$ & $-.280 * *$ & $-.176^{* * *}$ & $-.275^{* *}$ & $-.359 * *$ & $-.366^{* *}$ & $-.107 * *$ & $-.263 * *$ \\
\hline & & 0.000 & 0.000 & 0.000 & 0.000 & 0.000 & 0.000 & 0.000 & 0.000 \\
\hline & \multirow{2}{*}{$\begin{array}{l}\text { Employees' } \\
\text { intentions }\end{array}$} & $-.342 * *$ & $-.295 * *$ & $-.265 * *$ & $-.346^{* * *}$ & $-.361 * *$ & $-.389 * *$ & $-.210 * *$ & $-.300 * *$ \\
\hline & & 0.000 & 0.000 & 0.000 & 0.000 & 0.000 & 0.000 & 0.000 & 0.000 \\
\hline & \multirow{2}{*}{$\begin{array}{l}\text { The nature of } \\
\text { tasks }\end{array}$} & $-.200 * *$ & $-.175^{* *}$ & $-.145^{* *}$ & $-.150 * *$ & $-.252^{* *}$ & $-.294 * *$ & $-.066^{*}$ & $-.215^{* *}$ \\
\hline & & 0.000 & 0.000 & 0.000 & 0.000 & 0.000 & 0.000 & 0.020 & 0.000 \\
\hline & \multirow{2}{*}{ Work content } & $-.078^{* *}$ & $-.111^{* *}$ & $-.100 * *$ & $-.162 * *$ & $-.274 * *$ & $-.194 * *$ & 0.050 & $-.208^{* *}$ \\
\hline & & 0.002 & 0.000 & 0.000 & 0.000 & 0.000 & 0.000 & 0.081 & 0.000 \\
\hline & \multirow{2}{*}{ Work evaluation } & $-.184 * *$ & $-.179 * *$ & $-.140 * *$ & $-.226 * *$ & $-.355^{* * *}$ & $-.266^{* * *}$ & $-.089 * *$ & $-.222 * *$ \\
\hline & & 0.000 & 0.000 & 0.000 & 0.000 & 0.000 & 0.000 & 0.002 & 0.000 \\
\hline & \multirow{2}{*}{$\begin{array}{l}\text { Work } \\
\text { organization }\end{array}$} & $-.513 * *$ & $-.482 * *$ & $-.420 * *$ & $-.429 * *$ & $-.488 * *$ & $-.295 * *$ & $-.300 * *$ & $-.223 * *$ \\
\hline & & 0.000 & 0.000 & 0.000 & 0.000 & 0.000 & 0.000 & 0.000 & 0.000 \\
\hline & \multirow{2}{*}{$\begin{array}{l}\text { Work } \\
\text { management }\end{array}$} & $-.501 * *$ & $-.480 * *$ & $-.420 * *$ & $-.480 * *$ & $-.598^{* *}$ & $-.317 * *$ & $-.287 * *$ & $-.243^{* *}$ \\
\hline & & 0.000 & 0.000 & 0.000 & 0.000 & 0.000 & 0.000 & 0.000 & 0.000 \\
\hline & \multirow{2}{*}{$\begin{array}{l}\text { Physical } \\
\text { environment of } \\
\text { the work }\end{array}$} & $-.490 * *$ & $-.474 * *$ & $-.388^{* *}$ & $-.382 * *$ & $-.432 * *$ & $-.296 * *$ & $-.343 * *$ & $-.159 * *$ \\
\hline & & 0.000 & 0.000 & 0.000 & 0.000 & 0.000 & 0.000 & 0.000 & 0.000 \\
\hline & \multirow{2}{*}{ Work conditions } & $-.550 * *$ & $-.471 * *$ & $-.467^{* *}$ & $-.409 * *$ & $-.546^{* *}$ & $-.223^{* *}$ & $-.276^{* *}$ & $-.205^{* *}$ \\
\hline & & 0.000 & 0.000 & 0.000 & 0.000 & 0.000 & 0.000 & 0.000 & 0.000 \\
\hline
\end{tabular}

Notes:

** - statistical significance level $\alpha=0.01$ (hereafter $\alpha=0.01$ )

* - statistical significance level $\alpha=0.05$ (hereafter $\alpha=0.05$ )

\begin{tabular}{|lr|}
\hline Spearman correlation coefficient & Relationship \\
\hline $0.4<\mathbf{r}<=0.6$ & medium-strength \\
\hline $0.2<\mathbf{r}<=\mathbf{0 . 4}$ & weak \\
\hline $0.1<=\mathbf{r}<=0.2$ & very weak \\
\hline
\end{tabular}


As it can be seen from the research results presented in Table 10, the correlation indicators between MBPS and CSR in certain subcategories are not high but the reliability $\mathrm{p}=0.000$, which proves that the relationship is statistically significant. The relationship of medium strength was recorded between the work organization, the work management, the physical environment of the work, the work conditions and service quality and information for consumers, health and safety (corporate social responsibility, hereafter CSR) sub-categories. The sub-category of work organization (MBPS) has a medium correlation with the CSR sub-category of responsibility in the relations with the employees. The work management (MBPS) sub-category correlates with the responsibility in relations with the public as well as responsibility in the relations with the employees CSR sub-categories. The sub-category of the work conditions (MBPS) has a medium strength correlation with the sub-categories of the responsibility for environment and the responsibility in the relations with the employees.

\section{Results}

1512 employees representing 34 organizations participated in the research. The socio-demographic information on the respondents is presented in the tables below:

Table 11. Socio-demographic information on the respondents

\begin{tabular}{|c|c|c|c|}
\hline Gender & & Frequency & Percentage \\
\hline Male & & 521 & $34.5 \%$ \\
\hline \multirow[t]{2}{*}{ Female } & & 991 & $65.5 \%$ \\
\hline & Total: & 1512 & $100 \%$ \\
\hline Nationality & & Frequency & Percentage \\
\hline Lithuanian & & 1500 & $99.3 \%$ \\
\hline Russian & & 5 & $0.3 \%$ \\
\hline Polish & & 5 & $0.3 \%$ \\
\hline \multirow[t]{2}{*}{ Other } & & 2 & $0.1 \%$ \\
\hline & Total: & 1512 & $100 \%$ \\
\hline Age & & Frequency & Percentage \\
\hline $18-25$ years old & & 115 & $7.7 \%$ \\
\hline 26-30 years old & & 206 & $13.6 \%$ \\
\hline 31-35 years old & & 191 & $12.6 \%$ \\
\hline $36-40$ years old & & 256 & $16.9 \%$ \\
\hline 41-45 years old & & 269 & $17.8 \%$ \\
\hline 46-50 years old & & 206 & $13.6 \%$ \\
\hline 51-60 years old & & 235 & $15.5 \%$ \\
\hline \multirow[t]{2}{*}{ Over 61 years old } & & 34 & $2.3 \%$ \\
\hline & Total: & 1512 & $100 \%$ \\
\hline Marital Status & & Frequency & Percentage \\
\hline Single & & 223 & $14.7 \%$ \\
\hline Married & & 918 & $60.7 \%$ \\
\hline Divorced & & 196 & $13.0 \%$ \\
\hline \multirow[t]{2}{*}{ In cohabitation } & & 175 & $11.6 \%$ \\
\hline & Total: & 1512 & $100 \%$ \\
\hline Education & & Frequency & Percentage \\
\hline Higher & & 698 & $46.2 \%$ \\
\hline Advanced vocational training & & 479 & $31.7 \%$ \\
\hline Professional & & 183 & $12.1 \%$ \\
\hline Compulsory & & 149 & $9.9 \%$ \\
\hline \multirow[t]{2}{*}{ Primary } & & 3 & $0.1 \%$ \\
\hline & Total: & 1512 & $100 \%$ \\
\hline Working Experience & & Frequency & Percentage \\
\hline Up to1 year & & 68 & $4.5 \%$ \\
\hline $1-3$ years & & 148 & $9.8 \%$ \\
\hline 4-7 years & & 239 & $15.8 \%$ \\
\hline 8-10 years & & 273 & $18.1 \%$ \\
\hline
\end{tabular}




\begin{tabular}{|c|c|c|c|}
\hline $11-15$ years & & 238 & $15.7 \%$ \\
\hline 16-20 years & & 208 & $13.8 \%$ \\
\hline \multirow[t]{2}{*}{ Over 21 years } & & 338 & $22.3 \%$ \\
\hline & Total: & 1512 & $100 \%$ \\
\hline Work position & & Frequency & Percentage \\
\hline \multicolumn{2}{|l|}{ Top-level leadership } & 44 & $2.9 \%$ \\
\hline Leadership at the medial level & & 257 & $17.0 \%$ \\
\hline Leadership at the lowest level & & 168 & $11.1 \%$ \\
\hline \multirow[t]{2}{*}{ Ordinary employee/staff/expert } & & 1043 & $69.0 \%$ \\
\hline & Total: & 1512 & $100 \%$ \\
\hline Work Specifics & & Frequency & Percentage \\
\hline Services, direct communication with customers and waiters & & 1065 & $70.4 \%$ \\
\hline \multirow[t]{2}{*}{ Technical and physical work } & & 447 & $29.6 \%$ \\
\hline & Total: & 1512 & $100 \%$ \\
\hline Number of Employees & & Frequency & Percentage \\
\hline Up to 10 employees & & 65 & $4.3 \%$ \\
\hline 11-50 employees & & 397 & $26.4 \%$ \\
\hline 51-250 employees & & 757 & $50.2 \%$ \\
\hline \multirow[t]{2}{*}{ More than 251 employees } & & 287 & $19.1 \%$ \\
\hline & Total: & 1506 & $100 \%$ \\
\hline Sector & & Frequency & Percentage \\
\hline Private sector & & 753 & $49.8 \%$ \\
\hline \multirow[t]{2}{*}{ Public sector } & & 759 & $50.2 \%$ \\
\hline & Total: & 1512 & $100 \%$ \\
\hline Organization & & Frequency & Percentage \\
\hline Seeking to integrate a corporate social responsibility & & 329 & $21.8 \%$ \\
\hline Carrying a corporate social responsibility & & 354 & $23.4 \%$ \\
\hline Does not seek to integrate a social responsibility & & 44 & $2.9 \%$ \\
\hline \multirow[t]{2}{*}{ I do not know } & & 785 & $51.9 \%$ \\
\hline & Total: & 1512 & $100 \%$ \\
\hline
\end{tabular}

As it can be seen from the distribution of the results, the research was mainly attended by the respondent Lithuanian employees; the distribution of the respondents according to the age groups is more or less equal, with the exception of the age groups 18-25 and over the age of 61. According to the marital status, the highest proportion is of the respondents living in the marriage. With regard to education, the groups of the respondents having acquired higher and advanced professional education dominate. According to the work position, 69 per cent of the research respondents are regular employees/staff/experts, but much less is the per cent of the respondents in the leading positions. It was on the basis of the work subject specifics that the research aimed to identify what part of the respondents have a direct contact with clients, because this factor appeared to be quite significant from the results of the previous research in order in determine the prevalence of mobbing/bullying. The respondents doing the technical and physical work make 29 per cent. In order to identify the size of the organization, the item in accordance with the number of the employees was included into the questionnaire. As it can be seen from the results in Table 11, half of the respondents work in the organizations employing from 51 to 250, i.e. 50.2 per cent. By the sector the organizations belong to, as it can be seen, the distribution is equal. The distribution of the responses to the item about the status of their organization is especially significant in regard to the social responsibility aspect, as nearly 51,9 per cent of the respondents claimed they did not know. 
Table 12. MBPS and CSR with Regard to Employee Gender

\begin{tabular}{|c|c|c|c|c|}
\hline \multirow{2}{*}{ Categories } & \multirow{2}{*}{$\begin{array}{c}\text { Male } \\
(\mathbf{N}=\mathbf{5 2 1})\end{array}$} & \multirow{2}{*}{$\begin{array}{c}\text { Female } \\
(\mathbf{N}=991)\end{array}$} & \multicolumn{2}{|c|}{ t-test checking results } \\
\hline & & & $\mathbf{t}$ & p \\
\hline Factors related to the relations among employees & 0.05 & -0.03 & 1.358 & 0.175 \\
\hline $\begin{array}{l}\text { Factors related to the nature of tasks, work content and the } \\
\text { work }\end{array}$ & -0.06 & 0.03 & -1.617 & 0.106 \\
\hline $\begin{array}{llllll}\begin{array}{l}\text { Factors related to work organization and work } \\
\text { management }\end{array} & & & & \\
\end{array}$ & 0.05 & -0.03 & 1.449 & 0.148 \\
\hline $\begin{array}{l}\text { Factors related to physical work environment and work } \\
\text { conditions }\end{array}$ & 0.02 & -0.01 & 0.583 & 0.560 \\
\hline The behavior of a socially responsible organization & -0.06 & 0.03 & -1.621 & 0.105 \\
\hline The behavior of a socially responsible employee & -0.08 & 0.04 & -2.188 & 0.029* \\
\hline \multicolumn{5}{|c|}{$\begin{array}{l}\text { The analysis of the research results (Table 12) show that in most cases the employee gender is not statistically } \\
\text { significant even though the values send a signal of some differences. Applying Stjudent criterion (t-test) of the } \\
\text { statistical significance level } 0.05 \text {, it was recorded that the employee gender is a statistically valuable factor just in } \\
\text { regard to the behavior of a socially responsible employee. This method does not highlight the reasons from the deep, } \\
\text { however, the analysis shows that the differences become apparent in the behavior of employees (the estimates for } \\
\text { men are negative, while the estimates for women are positive), even though the statistical indicators of the other } \\
\text { categories do not show this. The other surveys on mobbing/bullying (Žukauskas, Vveinhardt, 2009; Vveinhardt, } \\
\text { Streimikiené, 2016) revealed the complicacy of the estimation with regard to gender which could be explained by the } \\
\text { differences of the roles perceived by men and women. }\end{array}$} \\
\hline
\end{tabular}

Table 13. MBPS and CSR with Regard to Work Position

\begin{tabular}{|c|c|c|c|c|}
\hline \multirow[b]{2}{*}{ Categories } & \multirow[b]{2}{*}{$\begin{array}{l}\text { Leaders } \\
(\mathrm{N}=469)\end{array}$} & \multirow{2}{*}{$\begin{array}{c}\text { Employees/ } \\
\text { officers/ } \\
\text { specialists } \\
(\mathrm{N}=1043)\end{array}$} & \multicolumn{2}{|c|}{ t-test checking results } \\
\hline & & & $\mathbf{t}$ & $\mathbf{p}$ \\
\hline Factors related to the relations among employees & 0.10 & -0.04 & 2.367 & $0.018^{*}$ \\
\hline $\begin{array}{l}\text { Factors related to the nature of tasks, work content and } \\
\text { the work }\end{array}$ & 0.16 & -0.07 & 4.016 & $0.000 * *$ \\
\hline 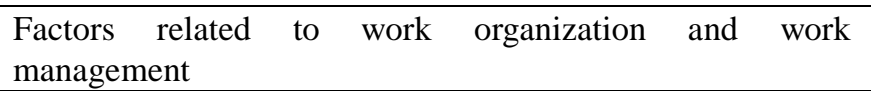 & 0.00 & 0.00 & -0.035 & 0.972 \\
\hline $\begin{array}{l}\text { Factors related to physical work environment and work } \\
\text { conditions }\end{array}$ & -0.13 & 0.06 & -3.349 & $0.001 * *$ \\
\hline The behavior of a socially responsible organization & 0.16 & -0.07 & 4.105 & $0.000 * *$ \\
\hline The behavior of a socially responsible employee & 0.14 & -0.06 & 3.409 & $0.001 * *$ \\
\hline \multicolumn{5}{|c|}{$\begin{array}{l}\text { In regard with this, two groups of employees were made, i.e., of the leading staff/positions and subordinate } \\
\text { employees (Table 13). Applying a single factor disperse analysis One-way ANOVA, strong and statistically valuable } \\
\text { differences between the criterion of mobbing / bullying as a psychosocial stressor and the criterion of a corporate } \\
\text { social responsibility have been identified in dependence of the position taken in an organization. A position in an } \\
\text { organization (leadership or subordinate) is not statistically significant just in assessing the factor related to work } \\
\text { organization and the factor of work management. At the level of an ordinary employee status, a major } \\
\text { non-acceptance of the items in the categories have been identified by the respondents, with the exception of the } \\
\text { factor related to work organization and work management as well as the factors related to physical work } \\
\text { environment and work conditions. }\end{array}$} \\
\hline
\end{tabular}


Table 14. MBPS and CSR with Regard to Employee Work Specifics

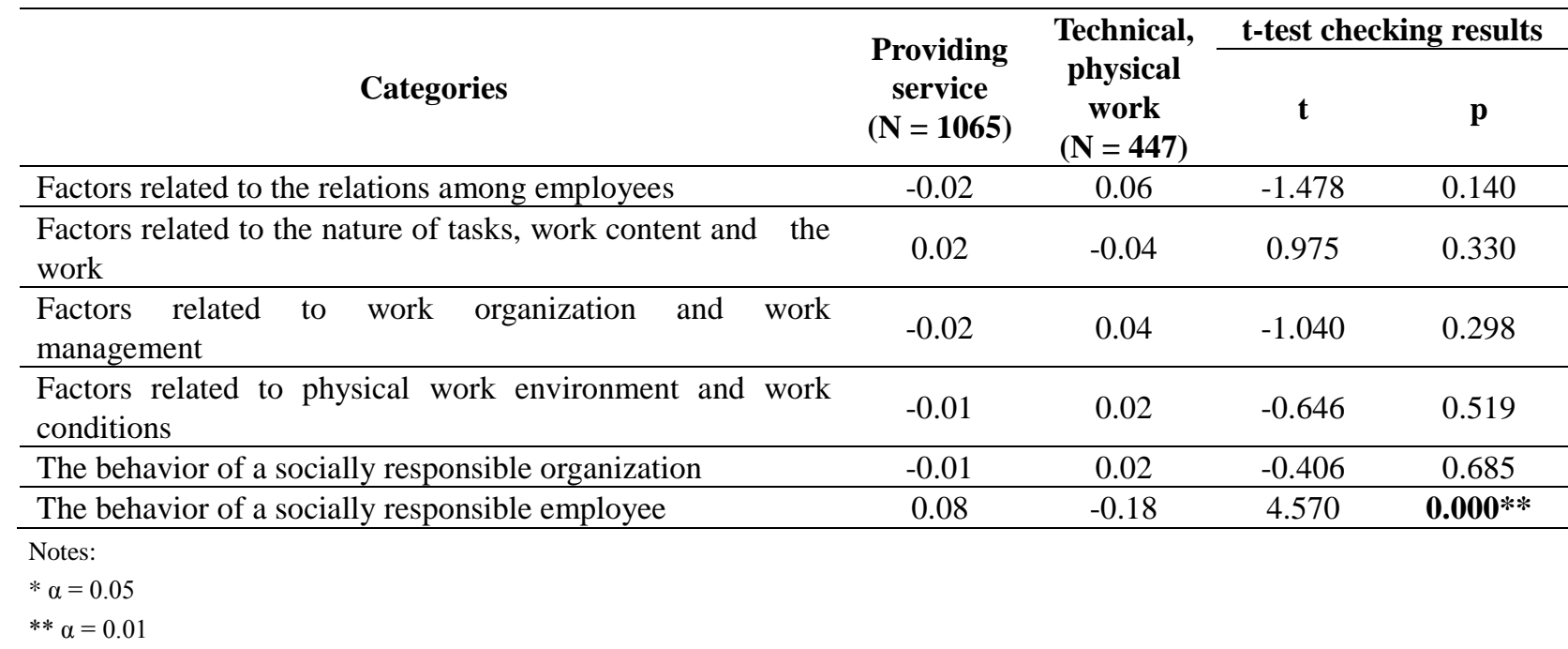

Quite differently from the post taken in the workplace, the nature of the task is statistically significant just in one aspect from the six (Table 14). Applying a single factor disperse analysis One-way ANOVA, a reliable relationship of statistical significance was recorded in the category of the behavior of a socially responsible employee; the positive and the negative values were significantly different. The respondents doing technical and physical tasks gave a negative evaluation of the items included into the category of socially responsible behavior.

Table 15. MBPS and CSR with Regard to Sector

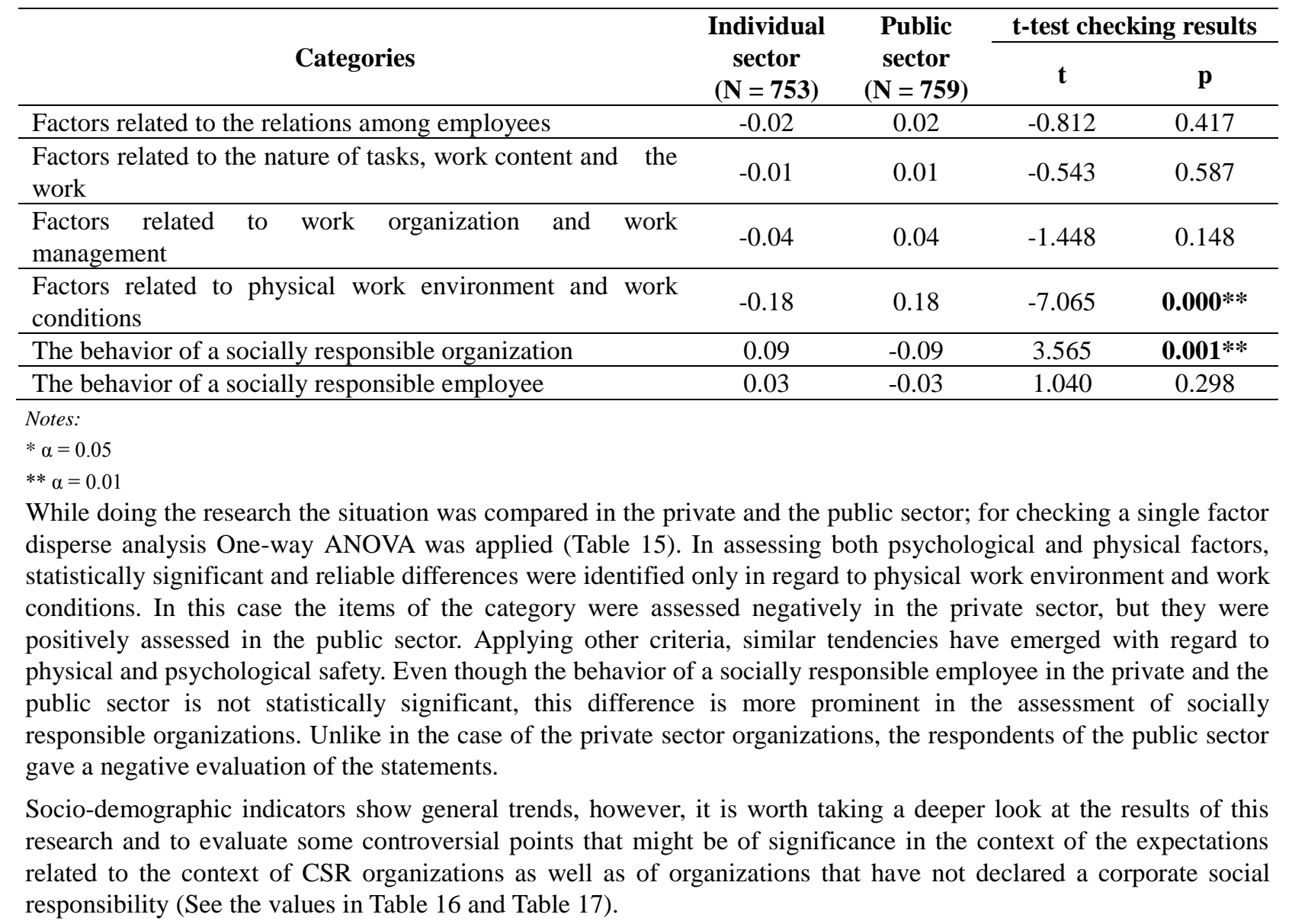


Table 16. MBPS: 15 Sub-categories as an Expression of Corporate Seeking to Become/ not to Become Socially Responsible

\begin{tabular}{|c|c|c|c|c|c|}
\hline Sub-categories & Categories & 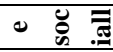 & $>\sum_{=}^{0}$ & 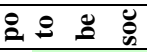 & \& \\
\hline Communication of employees & \multirow{8}{*}{$\begin{array}{c}\text { Factors related to the } \\
\text { relations among } \\
\text { employees }\end{array}$} & 0.19 & -0.15 & -0.50 & 0.02 \\
\hline Isolation of employees & & 0.13 & -0.07 & -0.29 & 0.00 \\
\hline Reputation of employees & & 0.06 & -0.06 & -0.40 & 0.02 \\
\hline Demography of employees & & 0.18 & -0.05 & -0.33 & -0.03 \\
\hline Employees' views & & 0.12 & -0.02 & -0.25 & -0.03 \\
\hline Damage suffered by employees & & 0.07 & -0.08 & -0.31 & 0.02 \\
\hline Employees' sense of well-being & & 0.16 & -0.14 & -0.27 & 0.01 \\
\hline Employees' intentions & & 0.05 & -0.14 & 0.03 & 0.04 \\
\hline The nature of tasks & \multirow{3}{*}{$\begin{array}{l}\text { Factors related to the } \\
\text { nature of tasks, work } \\
\text { content and the work }\end{array}$} & 0.24 & -0.10 & -0.33 & -0.04 \\
\hline Work content & & 0.09 & -0.02 & -0.39 & -0.01 \\
\hline Work evaluation & & 0.10 & -0.01 & -0.28 & -0.02 \\
\hline Work organization & \multirow{2}{*}{$\begin{array}{c}\text { Factors related to work } \\
\text { organization and work } \\
\text { management } \\
\end{array}$} & -0.08 & -0.09 & -0.05 & 0.07 \\
\hline Work management & & -0.08 & -0.17 & 0.29 & 0.10 \\
\hline Physical environment of the work & \multirow{2}{*}{$\begin{array}{c}\text { Factors related to physical } \\
\text { work environment and } \\
\text { work conditions }\end{array}$} & -0.15 & -0.12 & 0.20 & 0.11 \\
\hline Work conditions & & -0.12 & -0.18 & 0.36 & 0.11 \\
\hline
\end{tabular}

\section{Notes:}

Statistical estimates

\section{$\mathrm{z}<\mathbf{- 0 . 2 5}$}

$\mathrm{z}>0.25$

However paradoxical it may seem, the statistical estimates show the problems of mobbing/bullying as a social stressor are more effectively solved by the organizations that have not declared corporate social responsibility rather than by socially responsible organizations or by the ones that strive for this status. It means that the psychosocial well-being of employees is not a crucial factor for CSR organizations or the ones seeking for such status in the context of CSR. On the other side, CSR organizations as well as the organizations seeking for this status usually organize the processes of work management and the work conditions better (except the criterion of the physical conditions of the work), however, they do not evaluate the aspects of safety with regard to negative relations and the quality of management. The reasons for that could be found in national CSR narratives oriented to environment protection and the relations with the public.

Table 17. Corporate Social Responsibility (CSR): 8 Sub-categories as an Expression of Corporate Seeking to Become/ not to Become Socially Responsible

\begin{tabular}{|c|c|c|c|c|c|}
\hline $\begin{array}{r}\text { Sub-categories } \\
\end{array}$ & Categories & ○ & $>\stackrel{0}{0}$ & 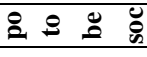 & 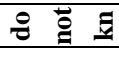 \\
\hline Services and their quality & \multirow{5}{*}{$\begin{array}{c}\text { Behavior of a socially responsible } \\
\text { organization }\end{array}$} & 0.09 & 0.18 & -0.05 & -0.11 \\
\hline Information for consumers, health and safety & & 0.11 & 0.23 & -0.17 & -0.14 \\
\hline Responsibility for environment & & 0.08 & 0.31 & -0.38 & -0.15 \\
\hline Responsibility in the relations with the public & & 0.09 & 0.30 & -0.67 & -0.13 \\
\hline $\begin{array}{l}\text { Responsibility in the relations with the } \\
\text { employees }\end{array}$ & & 0.16 & 0.16 & -0.34 & -0.12 \\
\hline $\begin{array}{l}\text { Responsibility of the employees against } \\
\text { consumers }\end{array}$ & \multirow{3}{*}{ Socially responsible employee behavior } & 0.05 & 0.11 & -0.23 & -0.06 \\
\hline Relations of the employees with clients & & 0.08 & 0.17 & 0.02 & -0.11 \\
\hline Relations of the employees with clients & & 0.03 & 0.13 & -0.10 & -0.07 \\
\hline
\end{tabular}

Statistical estimates

$\mathrm{z}>0.25$

$\mathrm{z}<\mathbf{- 0 . 2 5}$ 
Evaluating the positive and the negative z-values, two general tendencies can be highlighted and they both can be statistically significant. Firstly, organizations carrying corporate social responsibility are focused on the responsibility for environment protection and the responsibility in the relations with the public. Secondly, organizations that have not declared corporate social responsibility do not assess the aspects of the mentioned areas (alongside the relations with employees). Other factors, such as services and their quality, information for consumers, health and safety, the responsibility of the employees against consumers, relations of employees with the customers and the employees' approach to environmental protection are not statistically significant.

\section{Conclusion and Discussion}

Having analyzed the structure of the instrument in detail, it can be seen that the instrument consists of two main parts, namely, the part that deals with mobbing/bullying as a psychological stressor and the part dealing with corporate social responsibility. The part of mobbing / bullying as a psychological stressor comprises four categories: factors related to the relations among employees, factors related to the nature of tasks, the work content and work evaluation; factors related to work organization and work management and factors related to physical environment of the work and work conditions. The latter consist of fifteen subcategories that include 109 statements. The statements are aimed at identifying the communication gaps in the communication of employees, the isolation of employees, the reputation of employees and the problem of their attitudes to humiliation. This part contains the items dealing with the damage suffered by employees, employees' sense of well-being at work and, finally, the intentions of employees in regard to a definite organization, i.e., if an employee is planning to stay working there or is looking for a job in another workplace. In order to investigate the prevalence of mobbing/bullying as a psychological stressor in the workplace, not less significant is the issue of the nature of tasks and the work content as well as appropriate evaluation. This part of the questionnaire comprises the work specifics of the organization and a suitable physical environment and work conditions. The part dealing with corporate social responsibility consists of the following categories, i.e., the behavior of a socially responsible organization and the behavior of a socially responsible employee. CSR categories consist of eight sub-categories that comprise 48 statements aiming to identify not only the responsibility of the employees against consumers, the responsibility for environment and relations with customers but also the responsibility of the organizations in various aspects.

The psychometric characteristics identified in the research show high reliability of the questionnaire. The dispersion of the explained factors in all the sub-categories is higher than a required indicator of 10 per cent, i.e., varies from 50.82 (minimum result) to 78.61 (maximum result), which shows that there are no statements in the analyzed sub-categories to limit the dissemination. Cronbach alpha coefficient in all the analyzed sub-categories significantly exceed the minimal limit of 0.7, i.e., varying from 0.81 (minimum result) to 0.95 (maximum result). The minimum factorial weight in all the instrument sub-categories of the instrument notably exceeds the required limit of 0.3 , i.e., in the overall context of the instrument the minimum factorial weight varies from 0.43 (minimum result) to 0.83 (maximum result), which just proves the fact that there are no unsuitable statements in the sub-categories. The correlation average of the whole unit in all the sub-categories is higher than 0.2, i.e., from 0.49 (minimum result) to 0.78 (maximum result). The correlation coefficients in regard to sub-categories are not high; however, the interrelation is statistically significant.

Having analyzed the research results in regard to the socio-demographic characteristics of employees, it has been identified that gender is not a significant factor in the assessment of the physical and psychological safety criteria; however, the notable differences are highlighted in regard to the behavior of a socially responsible employee. It means that in similar conditions men and women are likely to behave differently. Therefore mobbing /bullying as a psychosocial stressor and corporate social responsibility in accordance to the safety and the social responsibility criteria vary in dependence on the work status in the organization. On the one side, it shows that ordinary employees suffer more from the factors related to the relations among employees, the nature of tasks, the work content and the work evaluation, the physical environment of the work and work conditions. On the other side, ordinary employees, in the contrary to the leaders, tend to evaluate the social responsibility of organizations negatively and to implement this attitude in their behavior. However, the work specifics, the spheres of technical, physical and services compared, do not reveal significant differences with the exception of the behavior of a socially responsible employee. If to compare the public and the private sector, significant differences of the psychological environment have not been identified, except the aspect of the physical work environment, which is not assessed as good in the private sector organizations. The significant differences have been identified in the behavior of both public and the private sector evaluating it with regard to a social responsibility. The organizations in the public sector are likely to behave with more social responsibility than the private sector organizations that, as it has been mentioned, provide poorer physical conditions of work. On the other side, this does not presuppose the differences in the behavior of employees 
in the public and the private sector.

\section{Acknowledgements}

This research was funded by a grant (No. The MIP-094/2014) from the Research Council of Lithuania.

\section{References}

Bagdonienè, D., \& Paulavičienè, E. (2010). Socialinès atsakomybès ir organizacijos vadybos sistemos integravimas. Ekonomika ir vadyba. Economics \& Management, 15, 366-373 [The integration of social responsibility and organizations management system, in Lithuanian].

Baltrušienè A., \& Karčiauskienė, D. (2010). İmonių socialinès atsakomybės studijos Lietuvoje bei jų tobulinimo galimybès. Šiuolaikinio specialisto kompetencijos: teorijos ir praktikos dermè, 1, 1-5 [Studies of corporate social responsibility in Lithuania and their improvement possibilities, in Lithuanian].

Baran Aksakal, F. N., Karasahin, E. F., Ugras Dikmen, A., Avci, E., \& Ozkan, S. (2015). Workplace physical violence, verbal violence, and mobbing experienced by nurses at a university hospital. Turkish Journal of Medical Sciences, 45(6), 1360-1368. http://dx.doi.org/10.3906/sag-1405-65

Berber, N., Susnjar, G. S., Slavic, A., \& Baosic, M. (2014). Relationship between corporate social responsibility and human resource management - as new management concepts - in Central and Eastern Europe. Inžineriné Ekonomika. Engineering Economics, 25(3), 360-369. http://dx.doi.org/10.5755/j01.ee.25.3.4222

Cramaruc, N. M. (2011). Assessment of workplace mobbing: reliability of a romanian version of the Negative acts questionnaire. 4th International Conference on Modern Research in Psychology - Trends and Prospects „Prospecting Advanced Research in Health, Education and Social Sciences“, 114-121.

Česynienè, R., Diskienè, D., \& Česynaitè, E. (2011). Socialinè atsakomybè darbuotojų atžvilgiu: lyginamoji viešojo ir verslo sektoriu analizè. Viešasis administravimas. Public Administration, 1, 19-26 [Corporate social responsibility to employees: comparative analysis in public and private sector, in Lithuanian].

de Pedro, M. M., Sanchez, M. I. S., Navarro, M. C., \& Izquierdo, M. G. (2008). Workplace mobbing and effects on workers' health. Spanish Journal of Psychology, 11(1), 219-227. http://dx.doi.org/10.1017/S1138741600004261

Dèjus, T. (2011). Safety of technological projects using multi-criteria decision making methods. Journal of Civil Engineering \& Management, 17(2), 177-183. http://dx.doi.org/10.3846/13923730.2011.576809

Dentith, A. M., Wright, R. R., \& Coryell, J. (2015). Those mean girls and their friends: bullying and mob rule in the academy. Adult Learning, 26(1), 28-34. http://dx.doi.org/10.1177/1045159514558409

Diržytė, A., Patapas, A., \& Fedkovič, U. (2014). Statutinių organizacijų darbuotojų subjektyvios gerovès ypatumai. Viešoji politika ir administravimas. Public Policy and Administration, 13(2), 307-317 [Subjective well-being of employees of statutory organizations, in Lithuanian]. http://dx.doi.org/10.13165/vpa-14-13-2-09

Efe, S. Y., \& Ayaz, S. (2010). Mobbing against nurses in the workplace in Turkey. International Nursing Review, 57(3), 328-334. http://dx.doi.org/10.1111/j.1466-7657.2010.00815.x

Escartin, J., Salin, D., \& Rodriguez-Carballeira, A. (2013). Workplace bullying or mobbing: gender similarities and differences in its perceived severity. Revista De Psicologia Social, 28(2), 211-224.

Faria, J. R., Mixon, F. G., \& Salter, S. P. (2012). An economic model of workplace mobbing in academe. Economics of Education Review, 31(5), 720-726. http://dx.doi.org/10.1016/j.econedurev.2012.04.004

Gudžinskienė, V., \& Trainienè, O. (2009). Socialinėse institucijose dirbančių asmenų savijautos ypatumai. Socialinis ugdymas. Social Education, 7(18), 30-41 [Peculiarities of social institution employees' well-being, in Lithuanian].

Gustainienė, L., Pranckevičienė, A., Bukšnytė-Marmienė, L., \& Genevičiūtė-Janonienė, G. (2014). Darbuotojo gerove ir pozityvi darbo aplinka: integruotas teorinis modelis. Organizaciju vadyba: sisteminiai tyrimai. Management of Organizations: Systematic Research, 69, 37-53 [Employee well-being and positive work environment: integrated theoretical model, in Lithuanian].

Hugh, L. D. (2011). Employee's mobbing at the workplace. Law Review, 13(4), 477-529.

Yildirim, A., \& Yildirim, D. (2007). Mobbing in the workplace by peers and managers: mobbing experienced by nurses working in healthcare facilities in Turkey and its effect on nurses. Journal of Clinical Nursing, 16(8), 1444-1453. http://dx.doi.org/10.1111/j.1365-2702.2006.01814.x 
Juščius, V. (2009). İmonių socialinė atsakomybė ir organizacijų tapatumas šiuolaikinės ekonominès krizės kontekste. Ekonomika ir vadyba. Economics \& Management, 14, 264-271. [Corporate social responsibility and corporate identity during the contemporary economic crisis, in Lithuanian].

Juščius, V., \& Snieška, V. (2008). Influence of corporate social responsibility on competitive abilities of corporations. Inžinerinè Ekonomika. Engineering Economics, 3, 34-44.

Karakaş, S. A., \& Okanli, A. (2015). The effect of assertiveness training on the mobbing that nurses experience. Workplace Health \& Safety, 63(10), 446-451. http://dx.doi.org/10.1177/2165079915591708

Klumbyte, E. (2011). Darbų saugos sistemos tobulinimas statyboje. Science: Future of Lithuania, 3(2), 26-29 [Work safety system improvement in construction, in Lithuanian]. http://dx.doi.org/10.3846/mla.2011.027

Lazutka, R., Skučienė, D., Žalimienė, L., Vareikytè, A., \& Kazakevičiūtè, J. (2008). Socialinių darbuotojų profesinès rizikos veiksniai. Socialinis darbas. Social Work, 7(3), 74-86 [Social workers occupational risks factors, in Lithuanian].

Liaudanskienè, R., Ustinovičius, L., \& Bogdanovičius, A. (2009). Evaluation of construction process safety solutions using the TOPSIS Method. Inžinerine ekonomika. Engineering Economics, 64(4), 32-40.

Malinauskiene, V. (2004). Bullying among teachers an Kaunas. The Fourth International Conference on Bullying and Harassment in the Workplace. Norway, Bergen.

Malinauskienè, V., Obelenis, V., \& Šopagienè, D. (2005). Psychological terror at work and cardiovacular diseases among teachers. Acta Medica Lituanica, 12(2), 20-25.

Marčinskas, A., \& Seiliūtè, J. (2008). Socialinė atsakomybè viešajame sektoriuje ir versle: lyginamoji analizè. Viešojo sektoriaus ir verslo raidos perspektyvos: pokyčiu tendencijos ir vertinimas. Perspectives of public sector and business development: tendencies of alteration and evaluation, 1(17), 70-79 [Social responsibility in public and business sectors: comparative analysis, in Lithuanian].

Mauricienė, I., \& Paužuolienė J. (2013). İmonių socialinės atsakomybès svarba: visuomenès požiūris. Regional Formation and Development Studies, 2(10), 123-132 [The Importance of corporate social responsibility: society perception, in Lithuanian].

Metzger, A. M., Petit, A., \& Sieber, S. (2015). Mentoring as a way to change a culture of academic bullying and mobbing in the humanities. Higher Education for the Future, 2(2), 139-150. http://dx.doi.org/10.1177/2347631115584119

Motlova, I., \& Lemrova, S. (2013). Mobbing as a hostile workplace behaviour and its occurrence in health care facilitie in the Czech Republic. International Conference Work and Organizational Psychology „Psychologie Prace a Organizace 2013“, 97-108.

Mulder, R., Pouwelse, M., Lodewijkx, H., \& Bolman, C. (2014). Workplace mobbing and bystanders' helping behaviour towards victims: the role of gender, perceived responsibility and anticipated stigma by association. International Journal of Psychology, 49(4), 304-312. http://dx.doi.org/10.1002/ijop.12018

Navickas, V., \& Kontautienè, R. (2013). The initiatives of corporate social responsibility as sources of innovations. Business: Theory \& Practice, 14(1), 27-34. http://dx.doi.org/10.3846/btp.2013.03

Pučetaitè, R. (2009). İmonių socialinès atsakomybės vadyba integralumo aspektu. Ekonomika ir vadyba. Economics \& Management, 14, 328-334 [Corporate social responsibility management analysis from the perspective of integrity, in Lithuanian].

Raišienè, A. G., \& Jonušauskas, S. (2013). Informacinių ir komunikaciniu technologijų ịtaka darbuotojų technostresui: situacijos Lietuvoje charakteristika. Informacijos mokslai. Information Sciences, 66, 78-95 [Influence of information and communication technologies on employee technostress: situation in Lithuanian organizations, in Lithuanian].

Simanavičienè, Ž., Kovaliov, R., \& Šubonytè, J. (2011). İmonių socialinès atsakomybès skatinimo politikos Lietuvoje SSGG analizè. Ekonomika ir vadyba. Economics \& Management, 16, 605-611 [Corporate social responsibility SWOT analysis policy in Lithuania, in Lithuanian].

Sotomayor, L., Eduardo, J., \& Pando M. M. (2014). Mobbing and symptoms of stress in public sector university faculty. Ciencia \& Trabajo, 16(49), 43-48. http://dx.doi.org/10.4067/S0718-24492014000100008

Stankiuvienė, A., Šukys, R., \& Čyras, P. (2006). Pokyčiai darbuotojų saugos ir sveikatos srityje, Lietuvai tapus ES 
nare. Technological \& Economic Development of Economy, 12(2), 146-151 [Changes in occupational safety and health after becoming Lithuania member of EU, in Lithuanian].

Šimanskienè, L., \& Paužuolienè, J. (2010). İmonių socialinès atsakomybès svarba Lietuvos organizacijoms. Management theory and studies for rural business and infrastructure, 20(1), 109-117 [Corporate social responsibility significant to Lithuanian organizations, in Lithuanian].

Šukys, R., Čyras, P., \& Šakenaitè, J. (2011). Economical loss due to non-compliance with requirements for personnel safety and health in Lithuanian construction sector. Journal of Civil Engineering \& Management, 17(2), 168-176. http://dx.doi.org/10.3846/13923730.2011.576841

Tartilaite, A. (2008). Konstitucinès nuostatos darbu saugos ir sveikatos srityje. Jurisprudencija. Jurisprudence, 8(110), 95-100, [Constitutional regulation of safety and health at work, in Lithuanian].

Usonis, J. (2007). Saugos ir sveikatos darbe reglamentavimo problemos kelių transporto srityje. Jurisprudencija. Jurisprudence, 1(91), 59-64 [Problems of legal regulation of health and safety at work in road transport sector, in Lithuanian].

Vveinhardt, J. (2011). Mobingo pasekmių individui, organizacijai, sociumui daugialypiškumo modeliavimas ir ịveikimo prielaidos. Ekonomika ir vadyba: aktualijos ir perspektyvos. Economics and Management: Current Issues and Perspectives, 2(22), 15-24 [Modelling of multipicity and defeat assumptions of the concequences of mobbing on individual, organizaion and socium, in Lithuanian].

Vveinhardt, J. (2016). Bullying and single cases of harassment in higher education organizations: managerial solutions to eliminate the problem. In: Dark Sides of Business and Higher Education Management (Ed. Agata Stachowicz-Stanusch \& Gianluigi Mangia) Business Expert Press, New York, in the first PRME Book Collection (in Press).

Vveinhardt, J., \& Andriukaitienė, R. (2014). Readiness of companies to become socially responsible: social behavior of an organization and an employee from a demographic viewpoint. Problems and Perspectives in Management, 12(2), 215-229.

Vveinhardt, J., \& Andriukaitiené, R. (2015). Determination of the level of management culture and social responsibility in a regional organisation of local self-government. Transformations in Business \& Economics, 14, 2(35), 204-223.

Vveinhardt, J., \& Andriukaitienè, R. (2015). Questionnaire verification of prevention of mobbing/bullying as a psychosocial stressor when implementing CSR. Problems and Perspectives in Management, 13(2), 57-70.

Vveinhardt, J., \& Stonkute, E. (2015). Corporate social responsibility as a brand: practical activity or social hypocrisy? Proceedings of the 3rd International Conference on Marketing and Business Development MBD2015 (Bucharest, Romania - June 25-27, 2015), 1(1), 9-20.

Vveinhardt, J., \& Streimikiene, D. (2016). Demographic, social and organizational characteristics on the levels of mobbing and single cases of harassment: the multicomplex approach. $E \& M$ - Ekonomie a Management (in Press).

Vveinhardt, J., \& Žukauskas, P. (2012). Mobingas darbuotoju santykiuose: individas, organizacija, sociumas. Monografija. Kaunas: Vytauto Didžiojo universiteto leidykla [Mobbing in employee relations: individual, organisation, society. Monograph, in Lithuanian].

Vveinhardt, J., Andriukaitienė, R., \& Cunha, L. M. (2014). Social capital as a cause and consequence of corporate social responsibility. Transformations in Business \& Economics, 13, 2A(32A), 161-184.

Vveinhardt, J., Andriukaitienė, R., \& Grančay, M. (2015). The preparation of companies in developing regions to become socially responsible: management culture assessment by employees. Transformations in Business \& Economics, 14, 2B (35B), 494-514.

Žukauskas, P., \& Vveinhardt, J. (2009). Socio-demographic characteristics of mobbing and discrimination in employee relations. Transformations in Business \& Economics, 8, 3(18), suppl. A, 129-147.

Žukauskas, P., Vveinhardt, J., Melnikas, B., \& Grančay, M. (2015). Dynamics of attack actions in the mobbing strategy: the case of Lithuania. Journal of Business Economics and Management, 16(4), 733-752. http://dx.doi.org/10.3846/16111699.2015.1068840 